\title{
GENETIC LITERACY LEVELS AND GENETIC SCREENING ATTITUDES ON MEDICAL STUDENTS IN INDONESIA: A NATIONAL SURVEY
}

\author{
Lantip Rujito1, Talitha Nandhika ${ }^{1}$, Dyah Woro Dwi Lestari², Miko Ferine ${ }^{2}$ and Amalia Muhaimin² \\ ${ }^{1}$ Department of Molecular Biology, Faculty of Medicine, Universitas Jenderal Soedirman, Purwokerto, Indonesia \\ 2 Department of Bioethics, Faculty of Medicine, Universitas Jenderal Soedirman, Purwokerto, Indonesia
}

Corresponding author: Lantip Rujito

Email: I.rujito@unsoed.ac.id

\begin{abstract}
Genetic literacy is an adequate knowledge that personally involves someone to comprehend and actively participate in genetic issues. An individual's genetic literacy level will influence their decisiveness and attitudes towards reoccurring genetic issues, including genetic screening. This research aimed to discover the relation between genetic literacy levels and genetic screening attitudes of medical students in Indonesia. The data were collected using a cluster sampling method composing of 492 students from 41 universities in Indonesia. Subjects filled the questionnaires, which have underwent validity and reliability test using online modality under local supervisors. Genetic literacy levels were divided into two categories: adequate ( $>50 \%)$ and inadequate $(<50 \%)$ levels, whereas the genetic screening attitude was categorized into consent and dissent. Of 492 respondents, only 121 people (24.59\%) have adequate genetic literacy levels. The study also reports that 262 respondents (60.16\%) agreed to the use of genetic screening. Using regression logistic, study found there was no relationship between genetic literacy and attitudes $(p>0.05)$. Disagreements about using genetic screening are more prevalent among female respondents rather than male respondents. The study showed no relationship between genetic literacy levels and genetic screening attitudes of medical students in Indonesia.
\end{abstract}

Keywords: Genetic literacy levels, genetic screening, medical students, Indonesia

\section{INTRODUCTION}

Over the last few decades, the role of genetic technology in health has improved and has significantly impacted individuals and communities. The focus of genetic researches on single-gene disorders is rare. Studies in the genetic field develop into assessments of genetic components in general to detect complex diseases such as cancer, diabetes, osteoporosis, and heart disease ${ }^{1}$.

The genetic susceptibilities that occur will raise the emergence of complex diseases that are problems for individuals or communities. Genes play a role in 9 out of the top 10 causes of death in the United States, including heart disease, cancer, and diabetes. It increases the potential for new approaches to prevention and treatment measures. Technological advances in prevention and treatment and genetic information have led to an increased need for genetic literacy in the community ${ }^{2}$. The level of one's genetic literacy will affect a person's decision-making and attitudes toward genetic issues. Also, genetic literacy may affect a person's attitudes toward service and genetic-based technology ${ }^{3}$.

One such gene-based technology is genetic screening. This technology allows detecting the risk of some genetic disorders from the

individual. Besides, genetic screening can also identify the genetically-derived conditions in the fetus or newborn so that the patient can tell whether or not there is a malformation to the fetus and can make a plan or seek more information about the problem. ${ }^{4}$

Public opinion about genetics is generally reasonable, although it depends on its type of application and its benefits. Overall, the technology that leads to disease detection and treatment is considered valuable. Even for diseases with limited clinical trial usefulness, such as psychiatric disorders, the community responds positively to it. Attitudes toward genetic screening, in which individuals can use the information for their health, are also reacted positively. A study in an Australian region revealed that almost $50 \%$ of pregnant women were tested for prenatal diagnosis, prenatal screening $(44.9 \%)$, diagnostic testing $(3.9 \%)$, or both $(3.2 \%)^{5}$. A comprehensive review of recent prenatal genetic screening trends and testing reported that the number of prenatal screening or testing requests increases every year since the invention of NIPT (non-invasive prenatal testing) ${ }^{6}$. Indonesia, as one of the biggest countries, has slow development regarding this subject; however, we found the facts that the prenatal testing providers exist but very limited in number and accessibility for ordinary people. Besides, the information and the data concerning this technology in Indonesia are still limited. There is no precise data regarding these issues. 
Medical students are expected to adapt and be aware of health technology, including screening properties and should comply with current opportunities. However, some literature states that not all health communities have enough fundamental knowledge about being knowledgeable and willing to adapt to health technology advancements ${ }^{7-9}$. Insufficient knowledge and awareness can result in gaps in providing adequate services to the community. This study explored the knowledge and attitudes, especially for genetic screening tests from medical students in Indonesia.

\section{METHODS}

\section{Study Design}

The study used an analytic observational study with a cross-sectional approach in the middle of 2018. Forty-one universities having a medical program in Indonesia were involved in data collection. The 492 number of respondentsachieved from Slovin formula-, collected using the cluster sampling method to obtain national coverage area. The universities were then grouped into 4 clusters based on the work area of ISMKI (Indonesian Medical Student Senate Association), and each region has at least 100 people the minimum sample size to be fulfilled to agree with proportional terms.

\section{Data sources and settings}

Subjects filled the questionnaires, which have underwent validity and reliability test $(p<0.05$ and Pearson correlation $>0.8$ ) using online modality using google form format, under local faculty supervisors. Subjects fulfilled questionnaires on the same day at their computer lab facility. The data then were stored and analyzed in principle investigator computer.

\section{Statistical analysis}

The level of genetic literacy used two-term categories: adequate and inadequate, while genetic screening attitude was divided into consent and dissent attitudes. Literacy category was achieved from the mark of correct answers, with the cut of point $50 \%$. A categorization of the attitude of using genetic screening was based on the median value obtained from the total score of the Likert scale of the 492 respondents. The median value of 74 was then used as the basis for categorizing the attitudes of the utilization of genetic screening. To determine is there any difference in the attitude of genetic screening among levels of literacy groups, the study used chi-square analysis $(p<0.05)$.

\section{Ethical Approval}

This study has been approved by Ethical Commitee of Faculty of Medicine Universitas Jenderal Soedirman Ref Number : 1523/KE/2016

\section{RESULTS}

From 492 respondents who fill out the questionnaire for this study, there were more female respondents $(63.41 \%)$ than male $(36.59 \%)$. Educational status of respondents showed that more preclinical students $(\mathbf{7 7 . 4 4 \% )}$ fill out questionnaires than clinical stage students (22.56\%). Most respondents came from region III (31.91\%), namely Central Java, Yogyakarta, East Kalimantan, Central Kalimantan and South Kalimantan (Table 1).

Table 1. Characteristics of the Respondents

\begin{tabular}{lll}
\hline Parameter & Frequency & Percentage (\%) \\
\hline $\begin{array}{l}\text { Gender } \\
\quad \text { Male }\end{array}$ & 180 & 36,59 \\
$\quad$ Female & 312 & 63,41 \\
$\begin{array}{l}\text { Age (years) } \\
\quad<20\end{array}$ & 264 & 53,6 \\
$\quad>20$ & 228 & 46,4 \\
Student stage & & \\
Preclinical Students & 381 & 77,44 \\
Clinical Students & 111 & 22,56 \\
Universities* & & 20,53 \\
$\quad$ Region I & 101 & 21,14 \\
$\quad$ Region II & 104 & 31,91 \\
$\quad$ Region III & 157 & 26,42 \\
$\quad$ Region IV & 130 & \\
\hline
\end{tabular}

* Region I : Sumatera, Region II : West Java, Jakarta, West Kalimantan Region III: Central Java, Yogyakarta, East Kalimantan, Central Kalimantan, South Kalimantan Region IV: East Java, Bali, Nusa Tenggara, Sulawesi, Maluku, Papua.

Most respondents $(52.44 \%)$ inform that they were very interested in the news and matters in the field of science technology (Figure 1). Figure 2 shows that only $71(14,43)$ respondent who report no common disease in their family, and the remain respondents $(85.57 \%)$ notified to have a family history of passing diseases from generation to generation. Of 492 respondents, only 121 people $(24.59 \%)$ have adequate genetic literacy levels (Table 2). This level was more 
prevalent among female respondents than male respondents. It can be seen from the comparison between respondents and adequate and

inadequate genetic literacy levels in each category based on gender (Table 5). The study also reports that 262 respondents $(60.16 \%)$ agreed to the use of genetic screening. Disagreements about using genetic screening were more prevalent among female respondents rather than male respondents (Table 3). The attitude seems equally distributed among individuals, both inadequate and adequate levels of genetic literacy. The study revealed that there was no relationship between the genetic literacy level and genetic screening attitudes on medical students in Indonesia (Table 4).

Table 2. Level of Respondents Genetic Literacy Between Regions

\begin{tabular}{lllllll}
\hline & Region 1 & Region 2 & Region 3 & Region 4 & Frequency & Percentage (\%) \\
\hline Adequate & 19 & 21 & 46 & 35 & 121 & 24,59 \\
Inadequate & 82 & 83 & 111 & 95 & 371 & 75,41 \\
\hline Total & 101 & 104 & 157 & 130 & 492 & 100 \\
\hline
\end{tabular}

Table 3. Distribution of Genetic Literacy Levels and Genetic Screening Attitudes according to the gender $(n=492)$

\begin{tabular}{lll}
\hline \multicolumn{1}{c}{ Parameter } & \multicolumn{2}{c}{ Gender } \\
\cline { 2 - 3 } & Female & Male \\
\hline $\begin{array}{l}\text { Genetic Literacy Levels } \\
\text { Adequate } \\
\text { Inadequate }\end{array}$ & $80(16,26 \%)$ & $41(8,33 \%)$ \\
$\begin{array}{c}\text { Genetic Screening Attitudes } \\
\text { Consent }\end{array}$ & $232(47,15 \%)$ & $139(28,25 \%)$ \\
Dissent & $151(25,41 \%)$ & $79(14,43 \%)$ \\
\hline
\end{tabular}

\section{Interest in News and Things in Science Technology}

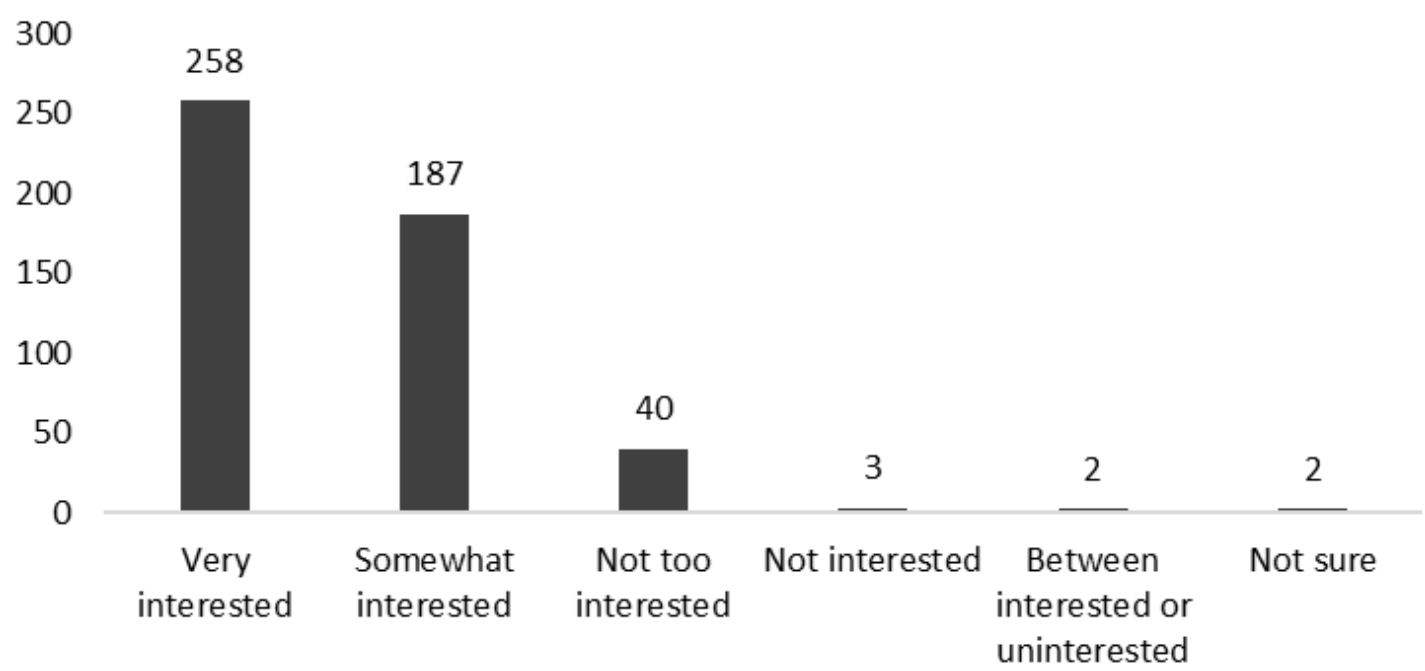

Figure 1. Survey on Interest in News and Things in Science Technology 


\section{Distribution of respondents with common diseases in the family}
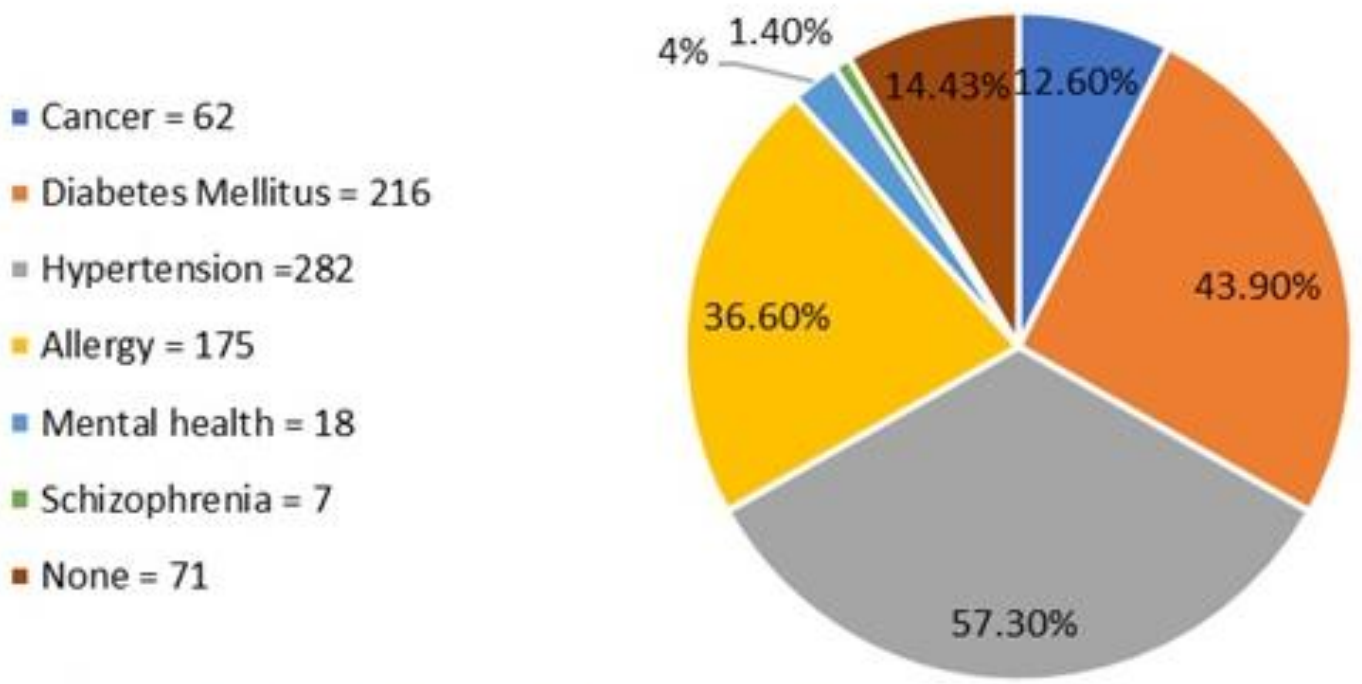

* respondents may choose more than 1 options

Figure 2. Distribution of common disease in the family

Table 4. The Relation Between Genetic Literacy Levels and Genetic Screening Attitudes on Medical Students in Indonesia

\begin{tabular}{lllll}
\hline \multirow{2}{*}{$\begin{array}{c}\text { Genetic Literacy } \\
\text { Levels }\end{array}$} & \multicolumn{2}{c}{ Attitudes } & \multicolumn{1}{c}{ Total } & p-value \\
\cline { 2 - 4 } & Dissent & Consent & $371(75,40 \%)$ & 0,59 \\
\hline Inadequate & $176(35,77 \%)$ & $195(39,63 \%)$ & $121(24,60 \%)$ & \\
Adequate & $54(10,98 \%)$ & $67(13,62 \%)$ & $492(100 \%)$ & \\
\hline Total & $230(46,75 \%)$ & $262(53,25 \%)$ & & \\
\hline
\end{tabular}

\section{DISCUSSION}

Scientists doubt the idea of applied genomics to public health services. Doctors also feel that the integration of genomes to their practices is still in the distant future ${ }^{10}$. There is limited information regarding how the development of genetics nowadays has shaped public opinion on genetics. Understanding an individual's attitude and trust can become a guide in communication efforts by explaining the misunderstanding and discrepancy in knowledge ${ }^{11}$.

Table 1 shows that male is fewer than female. This phenomenon happens to all medical faculties in Indonesia. According to the latest data, female dominate the proportion of gender in Indonesian medical faculty ${ }^{12}$. The distribution of medical faculties in Indonesia is most common in the western part of Indonesia. Table 1 consists of 4 regions, but it is not evenly divided proportionally between eastern and western Indonesia. Representatives of eastern Indonesia were East Kalimantan, Nusa Tenggara, Sulawesi, Maluku, and Papua.
Out of 492 respondents, there are 371 people $(75,41 \%)$ with inadequate genetic literacy levels. Previous studies of genetic literacy levels in other countries show a little bit different results. A recent study conducted among the public in the Netherlands reveals that $57 \%$ of respondents have insufficient genetic knowledge. In addition, according to a survey in the United States, $57.6 \%$ of respondents were familiar with genetics; however, on the difficult questions regarding genetics, only $22.2 \%$ of respondents answered correctly ${ }^{13}$.

Compared with other previous data, Indonesia's genetic literacy levels, especially in medical students, show a lower level. There were only $24.60 \%$ of 492 respondents who have an excellent genetic literacy level. Several factors can be proposed as the main problem of this issue. One of the causal factors is the lack of education programs regarding genetics. According to the research conducted in the United States and several other countries, the lack of education regarding health service work candidates' genetics becomes a significant factor that limits genetics' integration to health services. This specific deficiency consists of the amount and 
the content type in the education curriculum and knowledge related to genetics and the expertise of doctors, nurses, and other professional health services workers when they enter the practice clinic. ${ }^{14}$.

The Indonesian Doctor Competency Standard mentions that the lessons related to single genes disorders such as haemophilia, albino, phenylketonuria, thalassemia, and other chromosomal disease are marked as a 'good' to know ${ }^{15}$. It indicates that the portion of genetic lessons in medical education in Indonesia is still minimal. However, many common polygenic diseases such as hypertension, diabetes mellitus, asthma, and allergies are taught on clinical attention, not deep into the genes causality. The presentation of genetic lessons compared to all material in the preclinical curriculum is only 2.9$5 \%$. This fact may play a role in why genetic literacy is limited.

The medical curricula in Indonesia are divided into four competencies. The first standard is to enable the medical student to recognize clinical symptoms and know how to obtain more information on diseases. In standard 2, general practitioners are expected to make clinical diagnoses based on physical examinations and supports. Management of the diseases on competency standard one and two will be referred to the appropriate specialist and subspecialists. Standard 3 and 4 contain diseases that students must be able to manage and give appropriate therapy. It may degrade the interest and awareness of general medical students to study genetic diseases in-depth because they are not required to provide therapy for genetic diseases. The limitation process of learning genetic will be directly proportional to the level of one's genetic literacy.

Other factors that can cause low levels of genetic literacy are the lack of awareness and health workers' interest in studying genetics. According to a recent survey, it is found that awareness, experience, opinion, and readiness of a doctor in health care in answering questions about genetic examinations is still low. Powel and friends report that only $15 \%$ of 382 respondents are ready to discuss the topic with their patients about genetics background ${ }^{16}$. Doctors from the other studies also believe that studying genetic diseases is unproductive for primary health care ${ }^{17}$. Other surveys conducted by third and fourth-grade medical students in the United States and Canada show that only $26 \%$ is studying genetics as part of formal clinical education. In comparison, over $50 \%$ lack the necessary competence to apply genetic theory in the field of patient care ${ }^{18}$.

However, there are exciting data findings in Indonesia; Figure 1 shows that more than half of the respondents $(52.44 \%)$ express a great interest in news and matters in the field of science technology, but on the other hand, 371 respondents $(75.40 \%)$ from the regions have a low level of genetic literacy. Interest in a topic is generally followed by the individual's ability in that issue, but some studies mention inversion. The cause is related to the time of attraction. At the early step, cognitive abilities are minimal until the attraction is continued by attempting to delve into the topic and reach a significant level of knowledge 19. We assume that the respondents' high interest has not been followed by an effort to be more knowledgeable.

The report found there were no differences in genetic screening attitudes between any genetics literacy levels in Indonesia's medical students (Table 4). The relationship between a person's knowledge and the attitude toward using genetic screening or genetic technology shows more complex results than expected. In general, knowledge of less science will result in less positive attitudes toward genetics science utility. If people can be more educated about science, such as genetics, they will give a better response or attitude toward scientific technology, such as genomic development ${ }^{20}$. However, it cannot be separated from other factors that can affect a person's attitudes toward the use of genetic screening.

Attitudes toward a person's genetic screening may vary based on age, gender, and education level, as in the Theory of Planned Behavior. The theory suggests that background factors such as age, gender, ethnicity, socioeconomic status, mood, personality traits, and knowledge can influence an individual's attitude toward something ${ }^{21}$. Overall, based on some studies, a young person will show a higher interest in genetic screening and have a more positive attitude ${ }^{22,23}$. Males can also have more positive genetic screening attitudes because, in the decision-making process, males are more willing to take risks and prefer analysis. At the same time, female often involve intuition and personal emotions in the decision-making process ${ }^{24}$. Research conducted in Australia indicates that female have a better knowledge of genetics ${ }^{25}$. The data shows that females have better genetic literacy rates than males. Conversely, males have more positive attitudes toward genetic screening (Table 3 ).

The study reports that almost all families of respondents have experienced genetically inherited diseases, with a total of 421 respondents (Figure 2). This experience can positively affect a person's attitude toward genetic screening, primarily if the family refers to the doctor and gets examinations to perform diagnosis. Literature mentions that having a family member with inherited diseases will make another family more aware of screening approaches $^{26}$ 
Other people's experiences and opinions can be another factor that can influence the use of one's genetic screening, according to one component in the Theory of Planned Behavior ${ }^{27}$. Other people's opinions, especially doctors and other health workers, can help a non-expert understand complex genetic information and become an ideal source for making decisions about genetic screening ${ }^{28}$. Respondents may also involve their social experiences in shaping their beliefs, apart from the knowledge they have ${ }^{29}$.

In general, the community shows a positive attitude toward genetic researches and the latest genomic technology. However, this positive attitude is quite complicated and is influenced by beliefs about genetic research, the benefits of screening or genetic examinations, clinical benefits, and the field of genetic technology, for example, medical applications and cloning ${ }^{20}$. Indonesian society, in general, has a close bond with traditions and customs that are still strong. Their belief still influences the acceptance of new technology in their customs and community leaders. A small part of society, more open and accepting new inventions or technologies with more rational.

The study reports that respondents show high awareness of genetics and fairly good attitudes toward genetic screening. Respondents also know the functions and benefits of different genetic screening types to provide a positive attitude even if they do not have adequate genetic literacy. Students' views on the capabilities of genetic technology and screening in health are beneficial to supporting health in the future. However, such beliefs are not accompanied by sufficient literacy. Values as medical students that study various health topics will make students tend to gain a positive attitude about health-related topics, including genetic screening. According to Theory Planned Behavior, social values will affect the formation of individual attitudes towards certain topics.

\section{CONCLUSION}

There was no relationship between knowledge and genetic screening attitudes in the medical student of Indonesia

\section{Acknowledgement}

Authors wish to thanks to the Association of Medical Faculty of Indonesia for helping the data collection.

\section{Funding disclosure}

This study was funded by the Ministry of Research, Technology, and Higher Education Indonesia. Grant BLU Unsoed 2018.

\section{Ethical Statement}

Conflict of Interest
The authors declare that they have no conflict of interest in manuscript development and submission.

\section{REFERENCES}

1. Berkman ND, Sheridan SL, Donahue KE, Halpern DJ, Viera A, Crotty K, et al. Health literacy interventions and outcomes: an updated systematic review. Evid Rep Technol Assess (Full Rep) [Internet]. 2011 Mar;(199):1941. Available from: http://www.ncbi.nlm.nih.gov/pubm ed/23126607

2. Smith CD, Worsfold K, Davies L, Fisher R, McPhail R. Assessment literacy and student learning: the case for explicitly developing students 'assessment literacy.' Assess Eval High Educ [Internet]. 2013 Feb;38(1):44-60. Available from:

http://www.tandfonline.com/doi/ab s/10.1080/02602938.2011.598636

3. Goltz HH, Bergman M, Goodson P. Explanatory Models of Genetics and Genetic Risk among a Selected Group of Students. Front Public Heal [Internet]. 2016 Jun 6;4:111. Available from: http://www.ncbi.nlm.nih.gov/pmc/ articles/PMC4893687/

4. Wieacker $P$, Steinhard J. The Prenatal Diagnosis of Genetic Diseases. Dtsch Aerzteblatt Online [Internet]. 2010 Dec 3; Available from:

https://www.aerzteblatt.de/10.3238 /arztebl.2010.0857

5. Jaques $A M$, Collins VR, Muggli EE, Amor DJ, Francis I, Sheffield LJ, et al. Uptake of prenatal diagnostic testing and the effectiveness of prenatal screening for Down syndrome. Prenat Diagn. 2010 Jun;30(6):522-30.

6. Pös $O$, Budiš J, Szemes T. Recent trends in prenatal genetic screening and testing. F1000Research [Internet]. 2019 May 31;8:F1000 Faculty Rev-764. Available from: https://pubmed.ncbi.nlm.nih.gov/31 214330

7. Dodson $\mathrm{CH}$, Lewallen LP. Nursing students' perceived knowledge and attitude towards genetics. Nurse Educ Today [Internet]. 2011 May;31(4):333-9. Available from: 
https: / / linkinghub.elsevier.com/retr ieve/pii/S0260691710001267

8. Atif M, Arslan B, Quratulain S, Zainab A, Aminah N, Sonia A, et al. Knowledge, attitude, and practices of health care professionals regarding pharmacovigilance in Pakistan. Value Heal. 2016;19(3):A278.

9. Calsbeek $\mathrm{H}$, Morren $\mathrm{M}$, Bensing $\mathrm{J}$, Rijken M. Knowledge and Attitudes Towards Genetic Testing: A Two Year Follow-Up Study in Patients with Asthma, Diabetes Mellitus and Cardiovascular Disease. J Genet Couns [Internet]. 2007 Aug 21;16(4):493-504. Available from: http://doi.wiley.com/10.1007/s1089 7-006-9085-9

10. Evans JP, Meslin EM, Marteau TM, Caulfield T. Deflating the Genomic Bubble. Science (80- ) [Internet]. 2011 Feb 18;331(6019):861-2. Available from: https: / /www.sciencemag.org/lookup /doi/10.1126/science.1198039

11. Houwink EJ, van Luijk SJ, Henneman L, van der Vleuten C, Jan Dinant G, Cornel MC. Genetic educational needs and the role of genetics in primary care: a focus group study with multiple perspectives. BMC Fam Pract [Internet]. 2011 Dec 17;12(1):5. Available from: https: / /bmcfampract.biomedcentral .com/articles/10.1186/1471-2296$12-5$

12. Kementerian Pendidikan dan Kebudayaan Indonesia. Pangkalan data Pendidikan Tinggi [Internet]. Pangkalan data Pendidikan Tinggi. 2020. Available from: https: / / pddikti.kemdikbud.go.id

13. Abrams LR, McBride CM, Hooker GW, Cappella JN, Koehly LM. The Many Facets of Genetic Literacy: Assessing the Scalability of Multiple Measures for Broad Use in Survey Research. Zeeb $\mathrm{H}$, editor. PLoS One [Internet]. 2015 Oct 28;10(10):e0141532. Available from: https: / /dx.plos.org/10.1371/journal. pone.0141532

14. Kaye C, Korf B. Genetic Literacy and Competency. Pediatrics [Internet]. 2013 Dec 1;132(Supplement):S224 30. Available from: http://pediatrics.aappublications.or
g/cgi/doi/10.1542/peds.2013-1032G

15. Indonesia KK. Standar Kompetensi Dokter Indonesia. 2nd ed. Jakarta: Konsil Kedokteran Indonesia.

16. Powell KP, Christianson CA, Cogswell WA, Dave G, Verma A, Eubanks S, et al. Educational Needs of Primary Care Physicians Regarding Direct-toConsumer Genetic Testing. J Genet Couns [Internet]. 2012 Jun 30;21(3):469-78. Available from: http://doi.wiley.com/10.1007/s1089 7-011-9471-9

17. Guttmacher AE, Porteous ME, Mclnerney JD. Educating health-care professionals about genetics and genomics. Nat Rev Genet [Internet]. 2007 Feb;8(2):151-7. Available from: http: / / www.nature.com/articles/nr g2007

18. Mainous AG, Johnson SP, Chirina S, Baker R. Academic family physicians' perception of genetic testing and integration into practice: a CERA study. Fam Med [Internet]. 2013 Apr;45(4):257-62. Available from: http://www.ncbi.nlm.nih.gov/pubm ed/23553089

19. Walgermo BR, Frijters JC, Solheim OJ. Literacy interest and reader selfconcept when formal reading instruction begins. Early Child Res Q [Internet]. 2018;44:90-100. Available from:

http: / / www.sciencedirect.com/scie nce/article/pii/S088520061830022X

20. Etchegary H. Public attitudes toward genetic risk testing and its role in healthcare. Per Med [Internet]. 2014 Jul;11(5):509-22. Available from: https: / / www. futuremedicine.com/d oi/10.2217/pme.14.35

21. Caskey CT, Gonzalez-Garay ML, Pereira S, McGuire AL. Adult Genetic Risk Screening. Annu Rev Med [Internet]. 2014 Jan 14;65(1):1-17. Available from: http: / / www.annualreviews.org/doi/ 10.1146/annurev-med-111212144716

22. Cherkas LF, Harris JM, Levinson E, Spector TD, Prainsack B. A Survey of UK Public Interest in Internet-Based Personal Genome Testing. Ross JS, editor. PLoS One [Internet]. 2010 Oct 19;5(10):e13473. Available from: https://dx.plos.org/10.1371/journal. 
pone. 0013473

23. Makeeva OA, Markova V V., Roses $A D$, Puzyrev VP. An epidemiologicbased survey of public attitudes towards predictive genetic testing in Russia. Per Med [Internet]. 2010 May;7(3):291-300. Available from: https://www. futuremedicine.com/d oi/10.2217/pme.10.23

24. Shambaugh R. Different Brains, Different Behaviors: Why Women Lead Differently than Men [Internet]. 2016. Available from: https: / / www. huffingtonpost.com/re becca-shambaugh/different-brainsdifferen_b_9480952.html

25. Molster C, Charles T, Samanek A, O'Leary P. Australian Study on Public Knowledge of Human Genetics and Health. Public Health Genomics [Internet]. 2009;12(2):84-91. Available from: https: / /www.karger.com/Article/Ful IText/164684

26. Altaany Z, Khabour OF, Al-Taani G. Knowledge, Beliefs, and Attitudes Concerning Genetic Testing Among Young Jordanians. J Multidiscip Healthc [Internet]. 2019 Dec 11;12:1043-8. Available from: https: / /pubmed.ncbi.nlm.nih.gov/31 849479
27. Ajzen I. Attitudes, Personality and Behavior. 2nd ed. Berkshire, UK: Open University Press-McGraw Hill Education; 2005.

28. Morren M, Rijken M, Baanders AN, Bensing J. Perceived genetic knowledge, attitudes towards genetic testing, and the relationship between these among patients with a chronic disease. Patient Educ Couns [Internet]. 2007 Feb;65(2):197-204. Available from: https://linkinghub.elsevier.com/retr ieve/pii/S0738399106002308

29. Carver RB, Castéra J, Gericke N, Evangelista NAM, El-Hani CN. Young Adults' Belief in Genetic Determinism, and Knowledge and Attitudes towards Modern Genetics and Genomics: The PUGGS Questionnaire. Li D, editor. PLoS One [Internet]. 2017 Jan 23;12(1):e0169808. Available from: https://dx.plos.org/10.1371/journal. pone. 0169808 